\title{
Transparência na e da administração pública: (in) compatibilidade entre visibilidade e demais preceitos constitucionais a partir da análise ao caso concreto por meio da ADPF 144 do STF*
}

Patrícia Maino Wartha ${ }^{1}$

\section{Resumo}

O objetivo deste artigo é tratar a transparência da Administração Pública como essencial para a concretude do Estado Democrático de Direito, que pressupõe o cidadão como único titular e destinatário do poder. Assim sendo, todos os atos que em nome desse cidadão são executados deveriam ser por ele visualizados e fiscalizados. Contudo, essa visibilidade proposta não deve desrespeitar demais preceitos constitucionais que também são indispensáveis à consolidação do Estado Democrático. Primeiramente serão apresentadas as faces da visibilidade, no sentido de que por vezes, delas emana transparência e por vezes, ocultamento. Em seguida, tratar-se-á de um caso concreto, qual seja a ADPF 144 do STF, que contempla a tensão entre publicização das informações e o seu resguardo, que gera enfrentamento entre publicidade e privacidade, direito à informação e ao devido processo legal, contraditório e presunção de inocência. Por fim, entende-se que a informação publicizada deve evitar certos vícios, como as falácias e a pessoalidade, para que realmente se converta em transparência; o que demonstra ser uma pertinente conclusão para que efetivamente se alcance uma Administração Pública transparente em prol do interesse público e não dos interesses de uma minoria ou do próprio administrador público.

Palavras-chave: Administração Pública. Estado Democrático de Direito. Constituição. Transparência. Publicidade.

\footnotetext{
Artigo recebido em: 28/09/2010.

Artigo aprovado em: 01/02/2011.

1 Mestre em Direito Público pela UNISINOS (2010), advogada, professora universitária e coordenadora do núcleo de práticas jurídicas do Centro de Ensino Superior Cenecista de Farroupilha.
} 


\section{Transparência na e da administração pública}

Em se tratando de um Estado que se designe Democrático de Direito, requer-se uma Administração Pública transparente, que efetivamente se dê às vistas do público, exigindo, por conseguinte, o princípio da publicidade como forma de viabilizar a informação de relevância pública ${ }^{2}$ ao cidadão.

Desse mesmo Estado se espera que respeite a vasta gama de princípios constitucionalmente amparados.

Assim, tendo em vista que a Administração Pública transmite visibilidade, quando torna visíveis suas ações, disponibilizando-as aos seus administrados, a publicidade se mostra uma viável alternativa de instrumentalizar a transparência.

Contudo, sabe-se que em se tratando do cenário brasileiro, a transparência da e na Administração Pública é uma promessa que está ainda por cumprir, assim assevera Juarez Freitas: "[...] o fim da opacidade é uma das promessas não cumpridas da democracia" e sem visibilidade não há "salvação para o Estado Democrático". ${ }^{3}$

A sociedade exige, e mais do que isso, necessita visualizar as ações que em seu nome são praticadas, revelando inconcebível a crença em um poder invisível emanado pela Administração Pública, que resulta em ausência de credibilidade.

\footnotetext{
2 Limberger afirma que "O critério para determinar a legitimidade ou ilegitimidade das intromissões na intimidade das pessoas não é o da veracidade, mas exclusivamente o da relevância pública do fato divulgado, isto é, de que sua comunicação à opinião pública, mesmo não sendo verdadeira, torne-se necessária em função do interesse público do assunto sobre o que se informa”. LIMBERGER, Têmis. O direito à intimidade na era da informática: a necessidade de proteção dos dados pessoais. Porto Alegre: Livraria do Advogado, 2007. p. 135.

3 Juarez Freitas, prefaciando Julio Cesar Finger, assevera que "Com efeito, sem visibilidade adequada, não há salvação para o Estado Democrático. O fim da opacidade é uma das promessas não-cumpridas - para evocar Bobbio - da democracia”. FINGER, Julio Cesar. Constituição e publicidade: sobre os limites e possibilidades do controle jurisdicional da publicidade pessoal da administração. Porto Alegre: Livraria do Advogado, 2006. p. 07.
} 
Rev. Bras. de Políticas Públicas, Brasília, v. 1, n. 2, p. 31-50, jul./dez. 2011

Exatamente por isso, a transparência está diretamente relacionada à Administração Pública, tornando-se, pois, um de seus pilares, haja vista que tudo o que a ela se refere deve ser visível, não que isso signifique dizer que toda e qualquer informação deva ser noticiada, mas sim o que é de interesse público ${ }^{4}$ deve se dar às vistas da população.

Fazendo uso do termo "Estado-Administração", Juarez Freitas refere o Estado e a Administração Pública em suas múltiplas facetas, comprometidos com a concretização do vasto rol de direitos constitucionalmente previstos em favor do direito fundamental à boa administração pública. ${ }^{6}$

A par disso, a transparência ${ }^{7}$ torna-se elemento essencial ao alcance de um Estado-Administração eficaz na concretização do constitucionalmente previsto. ${ }^{8}$

${ }_{4}$ Interesse Público, nas palavras de Juarez Freitas “[...] significa a vontade geral legítima, o bem de todos sobre a vontade egoistamente articulada, não se confundindo com a vontade do aparato estatal, tampouco com o desejo da maioria”. FREITAS, Juarez. $O$ controle dos atos administrativos e os princípios fundamentais. 4. ed. São Paulo: Malheiros, 2009. p. 54.

5 FREITAS, Juarez. O controle dos atos administrativos e os princípios fundamentais. 4. ed. São Paulo: Malheiros, 2009. p. 463.

6 Juarez refere que o Estado do direito fundamental à boa administração pública é o promotor do bem de todos. FREITAS, Juarez. O controle dos atos administrativos e os princípios fundamentais. 4. ed. São Paulo: Malheiros, 2009. p. 144, 463, 479.

7 Um exemplo da visibilidade do poder, que se concretiza por meio da publicidade, conferindo transparência a todo o Estado Democrático de Direito é a Lei Complementar n. ${ }^{\circ}$ 101/2000, a chamada Lei de Responsabilidade Fiscal, que caracteriza a transparência fiscal como aprofundamento evolutivo setorial do princípio da publicidade, que é própria do regime democrático. Também relevante nesse contexto é salientar o portal Transparência RS, lançado oficialmente às 14 horas do dia 18 de Agosto de 2009, após um ano de elaboração do site www.transparencia.rs.gov.br, onde são disponibilizados gastos dos servidores, como despesas com diárias, sobretudo são omitidos salários de servidores e acesso a dados da administração indireta. TRANSPARÊNCIA: especialistas avaliam site de despesas. Zero-Hora, Porto Alegre, 19 ago. 2010. Política. p. 12.

8 Freitas, nesse viés, interioriza princípios constitucionais regentes das relações administrativas como o "princípio da publicidade ou da máxima transparência, com o direito à informação". FREITAS, Juarez. O controle dos atos administrativos e os princípios fundamentais. 4. ed. São Paulo: Malheiros, 2009. p. 155. 
Assim, considerando-se a transparência como indispensável, a publicidade ${ }^{9}$ assume fundamental importância, viabilizando a clareza do Estado e da Administração Pública, Estado-Administração, englobando assim todas as faces dos poderes Legislativo, Executivo e Judiciário, aí postas simplesmente para representar e administrar o poder pertencente à população, e que, portanto, por ela deve ser amplamente vislumbrado e avaliado.

Atente-se ao disposto no artigo 37 da Constituição Federal de $1988^{10}$ que traz a publicidade como um dever da Administração Pública, devendo, portanto, imperativamente se dar às vistas do público, agindo de forma a nada esconder, já que atua em nome dos administrados e, portanto, por eles deve ser visualizada.

Sob essa perspectiva, a ausência de publicidade dos atos praticados pelo poder público gera suspeita, dúvida e insegurança, uma vez que tudo o que beneficia a população é amplamente demonstrado e divulgado, característica da promoção política.

Em síntese, não há como se falar em Administração Pública se essa não se der às vistas do público.

9 Nesse sentido, Norberto Bobbio assevera que: "O tema mais interessante, com o qual é possível realmente colocar à prova a capacidade do poder visível de debelar o poder invisível, é o da publicidade dos atos do poder, que, como vimos, representa o verdadeiro momento de reviravolta na transformação do estado moderno que passa de estado absoluto a estado de direito". BOBBIO, Norberto. O futuro da democracia: uma defesa das regras do jogo. 5. ed. Rio de Janeiro: Paz e Terra, 1986. p. 103.

${ }^{10}$ O Artigo 37 da Constituição Federal de 1988 assim disciplina: "Art. 37. A administração pública direta e indireta de qualquer dos Poderes da União, dos Estados, do Distrito Federal e dos Municípios obedecerá aos princípios de legalidade, impessoalidade, moralidade, publicidade e eficiência [...]"; “\$ $1^{\circ}$ - A publicidade dos atos, programas, obras, serviços e campanhas dos órgãos públicos deverá ter caráter educativo, informativo ou de orientação social, dela não podendo constar nomes, símbolos ou imagens que caracterizem promoção pessoal de autoridades ou servidores públicos.”; “\$3 A lei disciplinará as formas de participação do usuário na administração pública direta e indireta, regulando especialmente: [...] II - o acesso dos usuários a registros administrativos e a informações sobre atos de governo, observado o disposto no art. 5, X e XXXIII; (Incluído pela Emenda Constitucional no 19, de 1998)". 
Rev. Bras. de Políticas Públicas, Brasília, v. 1, n. 2, p. 31-50, jul./dez. 2011

Com efeito, sabendo que todas as questões relacionadas ao Estado são públicas, a transparência se torna condição quase que existencial ao Estado Democrático de Direito, na medida em que não se refere a uma simples faculdade e sim a uma obrigatoriedade. ${ }^{11}$ É intrínseco ao ente público ser transparente, não representa uma característica, um adjetivo, mas sim a essência do Poder Público dar-se às vistas do povo. E é essa razão de sua existência - representar a coletividade e ser fiscalizado por ela. Nessa seara, o que é discutível é qual a abrangência e de que forma é instrumentalizada a visibilidade.

Como é sabido, tornou-se prática comum conferir publicidade a atos que beneficiem o administrador e que, por vezes, não condizem total ou parcialmente com a verdade, com o exclusivo intuito de obter prestígio, bem como quaisquer outras vantagens, ou em vista de velar algum fato que não deva vir a conhecimento do público.

${ }^{11}$ Cabe fazer aqui um breve aporte a atos que fogem à regra da publicidade, visibilidade e transparência da Administração Pública, os seiscentos e sessenta e três (663) atos secretos aprovados pelo Senado Federal Brasileiro, ou seja, não publicados, desconsiderando qualquer prerrogativa constitucional que prevê expressamente a obrigatoriedade da publicação. A mídia brasileira divulgou no mês de junho de 2009, que a Administração do Senado Federal editou, em um período de 15 anos, um total de 312 boletins administrativos, contendo 663 atos que não foram publicados, entre eles nomeações e favorecimentos pessoais. Os números constam do relatório final da comissão de sindicância criada para investigar a existência de atos irregulares nas últimas administrações da instituição. Esse lamentável acontecimento esboça claramente os efeitos maléficos da clandestinidade e do ocultamento, desrespeitando a Constituição e os princípios básicos do Regime Democrático de Direito. A população brasileira foi surpreendida pelo que a imprensa noticiou a respeito do Senado Federal: "Depois da revelação feita no mês passado por um estudo da Fundação Getúlio Vargas de que o Senado tinha mais 600 funções comissionadas e cargos com gratificação, descobre-se agora outra caixa-preta na Casa. Atos administrativos secretos foram usados para nomear parentes, amigos, criar cargos e aumentar salários. Levantamento feito por técnicos do Senado nos últimos 45 dias, a pedido da Primeira-Secretaria, detectou cerca de 300 decisões que não foram publicadas, muitas adotadas há mais de 10 anos. Essas medidas entraram em vigor, gerando gastos desnecessários e suspeitas da existência de funcionários fantasmas". COSTA, Rosa; COLON, Leandro. Senado acumula mais de 300 atos secretos para criar cargos e nomear - Parentes de políticos ganharam cargos sem que seus nomes fossem divulgados em publicações oficiais. Estadão de Hoje/Nacional, Brasília, 10 jun. 2009. Disponível em: <http://www.estadao.com.br/estadaodehoje/20090610/not imp385153,0.php >. Acesso em: 21 jul. 2009. 
E não suficiente, a publicização de informações tidas por privadas ou pendentes de comprovação, também se dá com certa frequência, o que resulta na tensão entre privacidade e publicidade, bem como entre outros dispositivos constitucionais, como ocorre na discussão pautada pela ADPF ${ }^{12} 144$ (Arguição de Descumprimento de Preceito Fundamental No 144 do Supremo Tribunal Federal - STF), que, nesse viés, merece exclusiva análise, uma vez que traz a discussão a respeito da possibilidade ou não da avaliação da vida pregressa de candidatos a cargos políticos que pudesse resultar em sua inelegibilidade.

\section{ADPF 144: análise ao caso concreto quanto às consequências da (in) visibilidade e a (in) compatibilidade com demais preceitos constitucionais}

Diante das tensões que possam se formar quando se preconiza a transparência na e da Administração Pública, bem como em outros conflitos que venham a existir, faz-se indubitável a análise ao caso concreto, haja vista ser insuficiente teorizar acerca do futuro e retratar, na medida do possível, o passado, deixando de avaliar o presente, a realidade, necessitando, pois, de soluções adequadas especificamente a cada caso.

A ADPF 144 do STF preconiza esse resgate ao caso concreto, trazendo como questionamento central se a publicização ou não das informações a respeito

\footnotetext{
${ }^{12}$ A Arguição de Descumprimento de Preceito Fundamental (ADPF) é a forma de controle concentrado de constitucionalidade existente no ordenamento jurídico brasileiro, que foi mais recentemente regulamentada através da Lei n 9.882/99 - "Art. 1o A argüição prevista no $₫ 1$ o do art. 102 da Constituição Federal será proposta perante o Supremo Tribunal Federal e terá por objeto evitar ou reparar lesão a preceito fundamental, resultante de ato do Poder Público".
} 
Rev. Bras. de Políticas Públicas, Brasília, v. 1, n. 2, p. 31-50, jul./dez. 2011

da vida pregressa do candidato a cargo político representa visibilidade ou ocultamento. ${ }^{13}$

Amplamente divulgado, o "caso das listas sujas", como notoriamente conhecido, inicialmente foi aplaudido pela população, acreditando que iriam definitivamente conhecer seus candidatos a representante a partir da avaliação da vida pregressa de todos aqueles que pleiteassem o cargo e, ao se deferir a inelegibilidade do candidato, acreditavam estar sendo protegidos daqueles então considerados "inaptos” à função.

Esqueciam que essa análise à vida pregressa também poderia advir de manobras políticas, uma vez que o divulgado poderia não corresponder à realidade, sendo apenas uma forma de ludibriar os eleitores à medida que se enfatizava algo inverídico e concomitantemente ocultava o fato real.

Evidenciam-se assim, a partir do estudo a esse caso concreto, dois pontos tensionantes: de um lado, tem-se o direito de informar e ser informado do cidadão, e os princípios de publicidade e transparência atinentes ao Poder Público, cuja fun-

${ }^{13}$ BRASIL. Supremo Tribunal Federal. Medida Cautelar em Arguição de Descumprimento de preceito fundamental 144. Relator: Min. Celso de Mello. Arguente(s): Associação dos Magistrados Brasileiros - AMB Advogados(a/s) Arguido(a/s): Tribunal Superior Eleitoral. Despacho: A Associação dos Magistrados Brasileiros questiona, na presente sede processual, a validade constitucional das interpretações emanadas do E. Tribunal Superior Eleitoral em tema de inelegibilidade fundada na vida pregressa dos candidatos (fls. 14/22 e 24/26), ao mesmo tempo em que sustenta, por incompatibilidade com o $\$ 9^{\circ}$ do art. 14 da Constituição, na redação que lhe deu a ECR no 4/94, a não-recepção de certos textos normativos inscritos na Lei Complementar no 64/90. Disponível em: <http://www.stf.jus. br/arquivo/cms/bibliotecaConsultaProdutoBibliotecaBibliografia/anexo/inelegibilidade. pdf $><$ http://www.stf.gov.br/portal/cms/verNoticiaDetalhe.asp?idCnteudo=92815\&caix aBusca=N $>$. Acesso em : 15 abr. 2011.

Por nove votos a dois, os ministros negaram o pedido da Associação dos Magistrados Brasileiros feito na Arguição de Descumprimento de Preceito Fundamental (ADPF) 144 para que a justiça eleitoral pudesse negar registro a políticos que respondem a processos. O julgamento ocorreu em agosto de 2008. (Consular ADPF $><144$, Rel. Min. Celso de Mello, julgamento em 6 de agosto 2008, Plenário, Informativo 514). No mesmo sentido: Rcl 6.534-AgR, Rel. Min. Celso de Mello, julgamento em 25 setembro de 2008, Plenário, DJE de 17 de outubro de 2008. Disponível em: <http://www.stf.jus.br/portal/constituicao/artigo.asp\#ctx1>. Acesso em: 27. out. 2009. 
ção é representar a coletividade. Em contrapartida, tem-se o direito fundamental à privacidade e os princípios constitucionais do contraditório, presunção de inocência e devido processo legal.

Considerando que os eleitores têm de conhecer os candidatos para que possam eleger o mais apto e, principalmente, o que realmente objetivar o benefício público, se está defronte a uma dificuldade, qual seja, desvendar as reais intenções e atributos dos candidatos, tendo em vista que todos mostram apenas o que lhes é conveniente, acobertando seus deméritos, momento em que a publicidade e a transparência, princípios constitucionais, deveriam ser observados.

Dessa monta, diante de princípios constitucionalmente previstos como o devido processo legal, contraditório e presunção de inocência, além da privacidade como direito fundamental, paira o questionamento: qual deve ter aplicabilidade nesse caso concreto? Visibilidade ou ocultamento? Publicidade ou privacidade? Direito à informação ou presunção de inocência?

A publicidade, concretizando o ideal de transparência tão desejável para que se tenha de fato uma Administração visível, em prol do coletivo, pode contrapor-se ao indivíduo em sua individualidade e privação quanto aos demais.

Nesse liame, ao passo que se viabiliza o direito/dever de informar e ser informado e os princípios de publicidade e transparência, pode-se estar limitando o direito à privacidade, o devido processo legal, o princípio do contraditório e da presunção de inocência.

Se por um lado, a avaliação da vida pregressa dos candidatos seria plenamente justificável e benéfica, visto que o eleitor teria conhecimento de fatos até então desconhecidos e que revelariam a identidade e, principalmente, as intenções, de seus futuros representantes. E nesse viés, a verdade se revelaria como a melhor alternativa e o ocultamento causador de dúvida e receio.

Por outro, revendo os conceitos de presunção de inocência, devido processo legal e contraditório, observar-se-á que até o trânsito em julgado, o acusado pode 
Rev. Bras. de Políticas Públicas, Brasília, v. 1, n. 2, p. 31-50, jul./dez. 2011

provar sua inocência e o descabimento da ação que lhe foi movida. Nessas condições, a avaliação da vida pregressa do candidato ocasionaria injustiças.

Vários são os pontos a se observar na discussão pautada pela ADPF 144 do STF, além da publicidade e privacidade, como o direito à informação, (in) elegibilidade, improbidade administrativa, ${ }^{14}$ devido processo legal, contraditório, presunção de inocência. Todos eles de suma importância para a concretude do Estado Democrático de Direito e de uma Administração Pública transparente, impessoal e eficiente.

Procedendo em primeira análise quanto ao direito de informar e ser informado, são constatadas, de imediato, duas faces: positiva e negativa. A mídia pode expressar e informar o povo, combatendo a censura, promovendo liberdade e transparência, e também pode representar um "veículo de perversão social", nas palavras de Dotti ${ }^{15}$ quando utiliza a informação como notícia de cunho sensacionalista e irresponsável, o que faz com que, em certos momentos, a liberdade

${ }^{14}$ Art. 14 da Constituição Federal $₫ 9^{\circ}$ - Lei complementar estabelecerá outros casos de inelegibilidade e os prazos de sua cessação, a fim de proteger a probidade administrativa, a moralidade para o exercício do mandato, considerada a vida pregressa do candidato, e a normalidade e legitimidade das eleições contra a influência do poder econômico ou o abuso do exercício de função, cargo ou emprego na administração direta ou indireta.

* Nova redação dada pela Emenda Constitucional de Revisão n 4, de 7.6.1994. Improbidade administrativa na legislação brasileira - A Lei Federal $n^{\circ} 8429 / 92$ trata dos atos de improbidade praticados por qualquer agente público. São abrangidos ainda aqueles que, mesmo não sendo agentes públicos, induzam ou concorram para a prática do ato de improbidade ou dele se beneficiem sob qualquer forma, direta ou indiretamente. Os atos incrimináveis são aqueles que importam vantagem ilícita, ou que causam prejuízo ao erário, ou que atentam contra os princípios da administração pública. As disposições desta alcançam todas as pessoas qualificadas como agentes públicos, na administração direta, indireta e fundacional, ainda que transitoriamente, com ou sem remuneração. E também as empresas incorporadas ao patrimônio público e as entidades para criação ou custeio o erário haja concorrido ou concorra com mais de $50 \%$ do patrimônio ou da receita anual. Os atos incrimináveis são aqueles que importam vantagem ilícita, ou que causam prejuízo ao erário, ou que atentam contra os princípios da administração pública. As penalidades envolvem ressarcimento do dano, multa, perda do que foi obtido ilicitamente, perda da função pública, suspensão dos direitos políticos (de 3 a 10 anos, conforme a hipótese) e proibição de contratar com o poder público.

${ }^{15}$ Nesse sentido, DOTTI, René Ariel. Proteção da vida privada e liberdade de informação: possibilidades e limites. São Paulo: Revista dos Tribunais, 1980. p. 128. 
reivindique se libertar da liberdade de informação, ou, no mínimo, libertar-se dos excessos atribuídos a essa liberdade, por mais que isso pareça contraditório.

Escritos irresponsáveis constroem e destroem facilmente a reputação e a dignidade das pessoas, ${ }^{16}$ e aí se faz presente a dicotomia bem e mal relacionada aos meios de comunicação.

Se por um lado, a atividade do pensar não pode ser confinada, oculta, ${ }^{17}$ por outro, noticiar informações inverídicas ou privadas pode infringir dispositivos constitucionais.

O direito de informar e ser informado parece colidir com o princípio da presunção de inocência, uma vez que as informações trocadas, por vezes, tratam de pessoas e crimes com processo em trâmite, sem o trânsito em julgado, como é o caso da divulgação da vida pregressa dos candidatos a cargos políticos, caso abarcado pela ADPF 144 .

Esse entrave gera inúmeras controvérsias à medida que ambos dispositivos tensionantes são imprescindíveis ao Estado Democrático de Direito brasileiro e, por vezes, conferindo efetividade a um deles, estar-se-ia restringindo o outro.

De todo modo, o primordial aqui é enfatizar que, não apenas na discussão em pauta, mas em todo cenário em que se afirme vigorar o Estado Democrático, deve-se preservar e fazer valer as garantias democráticas. E para tanto, o ponto chave consiste no princípio à presunção de inocência previsto no artigo $5^{\circ}$, inciso LVII da Constituição Federal de 1988 que assim disciplina: “[...] ninguém será considerado culpado até o trânsito em julgado de sentença penal condenatória”.

Esse princípio do estado de inocência ou da não culpabilidade garante que o indivíduo seja presumido inocente até o trânsito em julgado da sentença con-

${ }^{16}$ DOTTI, René Ariel. Proteção da vida privada e liberdade de informação: possibilidades e limites. São Paulo: Revista dos Tribunais, 1980. p. 129.

${ }^{17}$ JABUR, Gilberto Haddad. Liberdade de pensamento e direito à vida privada: conflitos entre direitos da personalidade. São Paulo: Revista dos Tribunais, 2000. p. 154-155. 
Rev. Bras. de Políticas Públicas, Brasília, v. 1, n. 2, p. 31-50, jul./dez. 2011

denatória. ${ }^{18}$ Nesse viés, como regra, o princípio do estado de inocência impede, ou ao menos deveria impedir, qualquer antecipação de juízo condenatório ou de culpabilidade. ${ }^{19}$

Conciliando a eficácia do princípio à discussão pautada pela ADPF 144, tem-se, consoante o julgamento de Eros Grau, ${ }^{20}$ que em se divulgando a vida pregressa dos candidatos a cargos políticos, estar-se-ía transformando a presunção de inocência em presunção de culpabilidade, ferindo assim o dispositivo constitucional previsto no artigo $5^{\circ}$ LVII, já que a notícia sensacionalista de um processo em trâmite pode transformar o mero suspeito em criminoso.

A presunção de inocência pressupõe a observância do devido processo legal e do contraditório. ${ }^{21} \mathrm{Na}$ medida em que o princípio ao contraditório representa a

${ }^{18}$ Com relação à coisa julgada, Nelson Nery Junior enfatiza que é instrumento de "pacificação social", de segurança jurídica, que representa manifestações do Estado Democrático de Direito, e, portanto, em descumprindo a coisa julgada, negar-se-á o próprio Estado Democrático de Direito. NERY JUNIOR, Nelson. Teoria geral dos recursos. 6. ed. São Paulo: Revista dos Tribunais, 2004. p. 501.

${ }^{19}$ No plano internacional, a Declaração Universal dos Direitos do Homem, de 10 de dezembro de 1948, consagra esse princípio em seu artigo XI.1: Art. XI.1: Todo homem acusado de um ato delituoso tem o direito de ser presumido inocente até que sua culpabilidade tenha sido provada de acordo com a lei, em julgamento público no qual tenham sido asseguradas todas as garantias necessárias à sua defesa.

${ }^{20}$ Eros Grau, em seu julgamento na ADPF 144 do Supremo Tribunal Federal, ressalta que por mais que não se fale em supremacia do público em relação ao privado, deve-se fielmente observar o principio da soberania popular e da democracia representativa, e nesse liame, somente o trânsito em julgado de uma sentença condenatória poderia impedir o acesso a cargos eletivos. p. 03 dos autos da ADPF 144 do STF.

${ }^{21}$ O princípio do Devido Processo Legal tem previsão Constitucional no artigo $5^{\circ}$, LIV, objetiva a garantia do cidadão, realizando a relação processo-democracia. Determina que a jurisdição penal, para ser válida, deve realizar-se através de um conjunto de atos que precisam ser executados conforme a ordem e a forma previamente estabelecidas na lei. Trata-se de uma garantia para o indivíduo, o qual não poderá ser privado de sua liberdade ou de seus bens sem a observância de um processo justo e legalmente codificado nas leis penais e processuais. Quanto ao princípio do contraditório, constitucionalmente previsto no artigo $5^{\circ}$, inciso $\mathrm{LV}$, pressupõe sempre a oitiva da outra parte, a fim de assegurar um processo e consequentemente uma decisão imparcial e, ao menos em tese, justa. Representa um corolário do princípio do devido processo legal, viabilizando resposta e a utilização de todos os meios de defesa em Direito admitidos. Aqui é pertinente ainda enfatizar o Devido Processo Legal administrativo disposto na Lei No 9.784 de 1.999 em seu artigo 3º. 
bilateralidade dos atos processuais, ele garante a igualdade e a isonomia dentro do processo, colocando acusação e defesa em um mesmo plano, sendo, portanto, inerente ao direito de defesa. Trata-se de questão de ordem pública sendo essencial a qualquer país que pretenda ser, minimamente, democrático.

Ao se garantir o princípio do contraditório, assegura-se que ninguém será condenado sem que lhe seja oportunizada a defesa. Nessas condições, é visível o tensionamento desse princípio com o direito à informação, à medida que limita a manifestação a respeito de informações que se encontrem sob a égide da prova em contrário e de decisões que careçam de trânsito em julgado.

Em que pese a divulgação da vida pregressa dos candidatos a cargos políticos, ferir tanto direitos quanto princípios constitucionalmente assegurados, como o devido processo legal, o contraditório, a presunção de inocência e inclusive o direito à privacidade, a não divulgação poderia ocasionar restrição a outros dispositivos, também com previsão constitucional, qual sejam o direito à informação, à liberdade de expressão e ao princípio da transparência.

Ainda, poder-se-ia afirmar que a divulgação da "lista suja",22 ou seja, dos processos em trâmite dos candidatos a cargos políticos, seria justificada quando da observância do significado de probidade atinente à administração pública, que, nas palavras de Juarez Freitas, refere-se a direito fundamental: “[...] o direito fundamental à administração pública proba que veda condutas eticamente não-universalisáveis, omissivas ou comissivas, inequivocamente desonestas", que, somada ao "[...] direito fundamental à administração pública transparente, que implica coibir

\footnotetext{
${ }^{22}$ Nesse sentido, é imprescindível destacar a Lei Complementar no 135/2010 que contempla o amplamente divulgado Projeto de Lei de Iniciativa Popular (PLP) 518/09 denominado "Ficha Limpa", que impedirá candidaturas de pessoas com condenações por colegiados da Justiça. Ver nota 29.
} 
a opacidade (negadora da idéia de democracia por definição)" ${ }^{23}$ bem motivaria a divulgação da vida pregressa dos candidatos a cargos políticos.

Nessa vertente, em possibilitando ao eleitor o conhecimento da vida pregressa dos candidatos, este poderia votar de forma consciente tendo em vista que lhe seria oportunizado conhecer realmente os candidatos a partir dos dados divulgados. No entanto, ao avaliar a vida pregressa, que engloba processos que ainda não transitaram em julgado, também se oportunizaria ao eleitor ser ludibriado, uma vez que alguns candidatos poderiam registrar falsas acusações para prejudicar a candidatura de seus concorrentes ao cargo, beneficiando-se dessa forma.

Nesse sentido, a publicização da vida pregressa dos candidatos a cargos políticos também poderia servir de ocultamento a manobras políticas, como supra salientado. Processos poderiam ser instaurados baseados em falsas acusações para prejudicar alguns candidatos, ou ainda, como forma de desviar a atenção a ilícitos realmente praticados. O que acarretaria enormes prejuízos para a vítima de descabidas acusações, visto que, provavelmente, teria sua inocência provada após a eleição, resultando, tal medida, em enorme injustiça já que não existia condenação transitado em julgado.

Atente-se que, sob esse olhar, o princípio da publicidade, que deveria resultar em transparência combatendo a invisibilidade, contribuiu justamente para o inverso, ocultamento da verdade em manobras políticas.

${ }^{23}$ Acrescentando ainda: "[...] aí incluída a complacência reprovável com os deslizes associados à arbitrariedade do 'coronelismo' - cumpre ter presente que a 'corrupção' se tornou transnacional, tecnologicamente sofisticada e, em certa medida, faz vulnerável o próprio Estado, mediante a captura de gestores ímprobos, todavia se nutre, no fundo, de uma cultura social propícia a fraudes e desmandos, cultura que debilita letalmente as instituições democráticas, de modo que reclama tratamento enérgico, para além das impotentes couraças antigas". FREITAS, Juarez. O controle dos atos administrativos e os princípios fundamentais. 4. ed. São Paulo: Malheiros, 2009. p. 36-37. 
Em face da (in)visibilidade, desvelam-se diversos aparentes entraves: publicidade ou privacidade, presunção de inocência ou direito à informação, sendo que a questão se torna ainda mais delicada uma vez que todos os polos tensionantes representam conquistas democráticas.

Em se tratando de elegibilidade e inelegibilidade, ${ }^{24}$ uma vez que essa discussão torna imprescindível o resgate a esses preceitos constitucionais, claramente vislumbra-se a impossibilidade de se impor a inelegibilidade a candidatos que tenham acusações em processos em trâmite. O artigo 15, III da Constituição Federal de 1988, assim enuncia: “Art. 15. É vedada a cassação de direitos políticos, cuja perda ou suspensão só se dará nos casos de: III - condenação criminal transitada em julgado, enquanto durarem seus efeitos." 25

${ }^{24}$ Inelegibilidade prevista no art. 1 letra n, da Lei Complementar no 5, de 29 de abril de1970 - inelegível os que respondessem processo judicial instaurado por denuncia do MP declarado inconstitucional pelo TSE no julgamento do recurso n. 4.462, Acórdão 5.864 . SUPREMO TIBUNAL FEDERAL. Inelegibilidade: bibliografia, legislação e juriprudência. Brasília, jul. 2008. Disponível em: <http://www.stf.jus.br/arquivo/cms/bibliotecaConsultaProdutoBibliotecaBibliografia/anexo/inelegibilidade.pdf. >. Acesso em: 15 abr. 2011.

${ }^{25}$ Pressupondo sentença transitada em julgado para inelegibilidade devem ser observados: o capítulo IV referente aos direitos políticos da Constituição Federal em seu artigo 14 ao disciplinar que: "A soberania popular será exercida pelo sufrágio universal e pelo voto direto e secreto, com valor igual para todos, e, nos termos da lei, mediante: [...] $\$ 9^{\circ}$ Lei complementar estabelecerá outros casos de inelegibilidade e os prazos de sua cessação, a fim de proteger a probidade administrativa, a moralidade para exercício de mandato considerada vida pregressa do candidato, e a normalidade e legitimidade das eleições contra a influência do poder econômico ou o abuso do exercício de função, cargo ou emprego na administração direta ou indireta. (Redação dada pela Emenda Constitucional de Revisão $\underline{n^{\circ}} 4$, de 1994). E a Lei Complementar No 64, de 18 de Maio de 1990, estabelece, de acordo com o art. 14, $\$ 9^{\circ}$ da Constituição Federal, casos de inelegibilidade, prazos de cessação, e determina outras providências. "Art. 1º̃a inelegíveis: I - para qualquer cargo: [...] e) os que forem condenados criminalmente, com sentença transitada em julgado, pela prática de crime contra a economia popular, a fé pública, a administração pública, o patrimônio público, o mercado financeiro, pelo tráfico de entorpecentes e por crimes eleitorais, pelo prazo de 3 (três) anos, após o cumprimento da pena;". Cabe ainda enfatizar aqui a recém promulgada Lei Complementar $n^{\circ} 35 / 2010$, que materializa o amplamente divulgado Projeto de Lei de Iniciativa Popular (PLP) 518/09 denominado "Ficha Limpa", que impedirá candidaturas de pessoas com condenações por colegiados da Justiça. Ver nota 29. 
Rev. Bras. de Políticas Públicas, Brasília, v. 1, n. 2, p. 31-50, jul./dez. 2011

Também é pertinente nesse âmbito, abordar a questão da ética na política, bastante em voga na atualidade, o que não parece preocupar os políticos haja vista sua real e exclusiva preocupação ser a permanência no cargo.

E exatamente quanto a essa ausência de dever para com a ética ${ }^{26}$ e para com outros princípios indispensáveis à eficiência almejada na Administração Pública, é que o princípio da transparência, concretizado por meio do princípio da publicidade, deve permear todos os atos que envolvem a gestão da coisa pública. Não deve haver segredos na administração dos bens públicos; os titulares de cargos nos três poderes, Executivo, Legislativo e Judiciário, uma vez que foram eleitos pelo voto ou ungidos ao posto por designação, precisam ter em mente que suas vidas e atitudes devem ser pautadas pela visibilidade de seus atos.

Sob essa perspectiva, poder-se-ía entender que o princípio constitucional que determina ser obrigatória a publicidade dos atos na vida pública, artigo $37,{ }^{27}$ deveria reger os processos judiciais em que autoridades são demandadas.

Todavia, o direito à privacidade e os princípios de presunção de inocência, do contraditório e do devido processo legal, que também possuem previsão constitucional, combatem veementemente os considerados pré-julgamentos, na medida em que se noticiam fatos investigativos como sendo incontestáveis.

Para tanto, paira o questionamento: é possível afirmar que o melhor caminho para o amadurecimento das regras democráticas é a divulgação de todos os fatos, sejam quem forem seus protagonistas e seja qual for o teor?

${ }^{26}$ Assim profere o eminente relator Ministro Celso de Mello, no julgamento à ADPF 144 do STF: “[...] os princípios de legalidade e moralidade devem funcionar consoante a ética da legalidade. Reportando-se à inquestionável importância quanto à observância aos princípios inerentes à Administração Pública, os quais não devem ser alvo de interpretações discricionárias, devendo fielmente reportar seus atos ao cumprimento à ética da legalidade, e nenhuma outra”. Disponível em: <http://www.stf.gov.br/portal/cms/verNoticiaDetalhe.asp?idCnteudo=92815\&caixaBusca=N $>$. Acesso em: 15 abr. 2011.

${ }^{27}$ Art. 37. Da Constituição Federal Caput: "A administração pública direta e indireta de qualquer dos Poderes da União, dos Estados, do Distrito Federal e dos Municípios obedecerá aos princípios de legalidade, impessoalidade, moralidade, publicidade e eficiência e, também, ao seguinte: [...]". 
Sob essa perspectiva, Eros Grau, ${ }^{28}$ em seu voto na ADPF 144, salienta que a avaliação da vida pregressa dos candidatos a cargos políticos causa incerteza e insegurança jurídica, enfatizando que a democracia reivindica o respeito ao devido processo legal e que em nosso ordenamento vigora a presunção de inocência e não de culpabilidade.

O que não pode cair no esquecimento é que toda e qualquer generalização é insensata frente a tantas exceções que comportam o ordenamento brasileiro.

Contudo, diante do aparente entrave trazido pela ADPF 144 entre publicidade e privacidade, entre o direito a informar e ser informado e o devido processo legal, o contraditório e a presunção de inocência, reflete-se que, em virtude de os processos constantes na relação da vida pregressa de cada candidato estarem em trâmite, não é possível noticiá-los, uma vez que a acusação não restou comprovada, havendo a possibilidade de resultar em inocência.

Embora se saiba que a ocultação da realidade beneficie o ilícito e contradiga a transparência exigível em todos os degraus da administração pública, deve-se dar proteção a algumas e determinadas exceções, o que não significa tornar como secretos atos que deveriam ser de conhecimento público.

Questiona-se se esse raciocínio fora observado no julgamento da ADPF 144, que consoante o Relator, Ministro Celso de Mello, restou decidido pelo STF que: “[...] a mera existência de inquéritos policiais em curso ou de processos judiciais em andamento ou de sentença penal condenatória ainda não transitada em julgado, além de não configurar, por si só, hipótese de inelegibilidade, também não impede o registro de candidatura de qualquer cidadão", conforme ocorre no caso

\footnotetext{
${ }^{28}$ Eros Roberto Grau, em julgamento na ADPF 144 do Supremo Tribunal Federal, reflete que, por mais que não se fale em supremacia do público em relação ao privado, deve-se fielmente observar o princípio da soberania popular e da democracia representativa.
} 
em tela, em que há ações criminais e ação civil pública de improbidade administrativa ajuizadas contra o candidato a cargo eletivo julgadas procedentes, embora sem trânsito em julgado. ${ }^{29}$

Semelhante ao caso pautado pela ADPF 144 do STF, tem-se a Lei Complementar no 135/2010, conferindo vigor ao Projeto de Lei de Iniciativa Popular (PLP) 518/09 denominado "Ficha Limpa", ${ }^{30}$ que chegou ao Legislativo com o aval de mais de 1,5 milhões de eleitores brasileiros, como amplamente noticiado, e que, embora tenha sido intensamente aplaudida como uma conquista democrática, ainda está sob o alvo de críticas, sob o argumento de inconstitucionalidade uma vez que poderia ferir outros princípios constitucionais, discussão que permeia (va) a ADPF 144 .

Não obstante, permanece a transparência como pressuposto da Administração Pública, pleiteando que a visibilidade dos assuntos públicos seja transmitida não apenas em território administrativo como em âmbito nacional, viabilizando a todo cidadão um Estado-Administração a ele disponível. Para tanto, necessita somar-se a todos os demais princípios constitucionalmente previstos, e não por eles ser violado.

Percebe-se então, que deveria ser banido o caráter “interesseiro" que ainda vigora na Administração Pública, onde o administrador toma providências em nome do "público", mas que resultam unicamente em benefícios pessoais, partidá-

${ }^{29}$ Disponível em: <http://www.tse.gov.br/sadJudSjur/pesquisa/actionBRSSearch.do?toc=tr ue\&docIndex $=0$ \&httpSessionName $=$ brsstateSJUT6249824\&sectionServer $=$ TSE $>$. Acesso em: 26 out 2009.

${ }^{30}$ Semelhante ao caso pautado pela ADPF 144 do STF tem-se a Lei Complementar ${ }^{\circ}$ 135/10, oriunda do Projeto de Lei de Iniciativa Popular (PLP) 518/09 denominado "Ficha Limpa", que representa um exemplo da publicidade diretamente relacionada à participação popular, que impede a candidatura de políticos condenados, em decisão transitada em julgado ou proferida por órgão judicial colegiado, desde a condenação até o transcurso do prazo de 8 (oito) anos após o cumprimento da pena, pelos crimes previstos no artigo $2^{\circ}$ da LC, chegando ao Legislativo com o aval de mais de 1,5 milhões de eleitores brasileiros - o que permitiu, de acordo com o que prevê a Constituição - a apresentação de um projeto de iniciativa popular ao Congresso Nacional para que ele seja discutido, e que de fato se concretizou. FREIO ético: avança projeto que exige ficha limpa. Zero-Hora, Porto Alegre, 22 mar. 2010. Política. 
rios, ou de uma minoria, o que é totalmente descabido, haja vista que a Administração Pública deve preconizar unicamente o interesse público e, portanto, deve o administrador abdicar de quaisquer subjetivismos em suas decisões e ações, já que é mero representante do poder, que é de titularidade do povo.

Constata-se então ser pertinente a proposição de critérios com amparo constitucional que condicionem a publicização da vida pregressa dos candidatos a cargo político a sua aplicação, como a impessoalidade e a verdade, viabilizando a concretização da transparência sem o desrespeito a outros preceitos constitucionais.

Em sendo impessoal e verdadeira a informação divulgada, fideliza-se a realidade da notícia evitando distorções, falácias e os interesses alheios ao público (pessoais do veiculador ou do administrador público).

Assim, em se aplicando ao caso pautado pela ADPF 144 os critérios de verdade e impessoalidade como condicionantes ao princípio da publicidade, ter-se-ía a presunção de inocência, representando a "verdade" do processo em trâmite, ou seja, revelando a inocência de uma acusação que ainda não fora definitivamente comprovada, já que carecedora de trânsito em julgado.

Assim, na expectativa de conferir a transparência indubitável à Administração Pública sem, contudo, ferir demais princípios, bem como direitos constitucionalmente amparados, deve-se preconizar o princípio da publicidade como transmissor de visibilidade e não de ocultamento. Sendo assim, é possível antever que, para que de fato a publicidade seja eficaz na transmissão de visibilidade, deve pressupor impessoalidade e verdade, abdicando de quaisquer vícios e intenções alheias às constitucionalmente previstas para que então se possa ter um Estado-Administração visível efetivamente. 


\title{
Transparency in public administration: (in)compatibility between visibility and other constitutional principles by analyzing the case through the fts 144 ADPF.
}

\begin{abstract}
The purpose of this article is to address the transparency of public administration as vital to the concreteness of the Democratic State of Law, which requires only the citizen as recipient and holder of power, therefore, assuming that all acts on behalf of citizens are run should be viewed and monitored by him. However, this visibility proposal shall not infringe other constitutional provisions that are also essential for the consolidation of democratic rule. First will appear the faces of the visibility, in the sense that sometimes emanates transparency and sometimes hiding. Then it will treat a case which is the ADPF 144 FTS, which includes the tension between information and publicity of her protection, which generates confrontation between publicity and privacy, right to information and due process, adversarial and presumption of innocence. Finally, it is understood that the information publicized should avoid certain vices, such as fallacies and personality, to really convert to transparency, which proves to be an appropriate conclusion so as to effectively reach a transparent public administration in the public interest and not the interests of a minority or of the public administrator.
\end{abstract}

Keywords: Public Administration. Democratic State of Law. Constitution. Transparency. Advertising.

\section{Referências}

BOBBIO, Norberto. O futuro da democracia: uma defesa das regras do jogo. 5. ed. Rio de Janeiro: Paz e Terra, 1986.

BRASIL. Tribunal Superior Eleitoral. Disponível em: <http://www.tse.gov.br/ sadJudSjur/pesquisa/actionBRSSearch.do? toc $=$ true \&docIndex $=0$ \&httpSessionNa me $=$ brsstateSJUT6249824\&sectionServer=TSE $>$. Acesso em: 26 out. 2009 .

CONSELHO FEDERAL DA ORDEM DOS ADVOGADOS DO BRASIL. Informativo $O A B$. Brasília, 2011. Disponível em: <http://www.oab.org.br/noticia. asp? id=19885 > . Acesso em: 11.05.2011. 
COSTA, Rosa; COLON, Leandro. Senado acumula mais de 300 atos secretos para criar cargos e nomear. Estadão.Com.Br. São Paulo, 2009. Disponível em: < http:// www.estadao.com.br/estadaodehoje/20090610/not imp385153,0.php $>$. Acesso em: 21. jul. 2009.

DOTTI, René Ariel. Proteção da vida privada e liberdade de informação: possibilidades e limites. São Paulo: Revista dos Tribunais, 1980.

FINGER, Julio Cesar. Constituição e publicidade: sobre os limites e possibilidades do controle jurisdicional da publicidade pessoal da administração. Porto Alegre: Livraria do Advogado, 2006.

FREIO ético: avança projeto que exige ficha limpa. Zero-Hora, Porto Alegre, 22 mar. 2010. Política.

FREITAS, Juarez. O controle dos atos administrativos e os princípios fundamentais. 4. ed. São Paulo: Malheiros, 2009.

JABUR, Gilberto Haddad. Liberdade de pensamento e direito à vida privada: conflitos entre direitos da personalidade. São Paulo: Revista dos Tribunais, 2000.

LIMBERGER, Têmis. O direito à intimidade na era da informática: a necessidade de proteção dos dados pessoais. Porto Alegre: Livraria do Advogado, 2007.

NERY JUNIOR, Nelson. Teoria geral dos recursos. 6. ed. São Paulo: Revista dos Tribunais, 2004.

SEISCENTOS e sessenta e três (663) atos secretos. Disponível em: <http:// clippingmp.planejamento.gov.br/cadastros/noticias/2009/6/24/relatorio-dizque-senado-teve-663-atos-secretos-nao-publicados-em-15-anos $>$. Acesso em: 15.03.2010.

SUPREMO TIBUNAL FEDERAL. Inelegibilidade: bibliografia, legislação e juriprudência. Brasília, jul. 2008. Disponível em: <http://www.stf.jus.br/arquivo/ $\mathrm{cms} /$ bibliotecaConsultaProdutoBibliotecaBibliografia/anexo/inelegibilidade. pdf.>. Acesso em: 15 abr. 2011.

TRANSPARÊNCIA: especialistas avaliam site de despesas. Zero-Hora, Porto Alegre, 19 ago. 2010. Política.

TRANSPARÊNCIA RS. Consulta aos gastos e receitas públicas. Porto Alegre. 2009. Disponível em: <www.transparencia.rs.gov.br $>$. Acesso em: 11. out. 2009. 